\title{
OVARIAN SERTOLI-LEYDIG CELL TUMOR: A RARE TUMOR WITH ATYPICAL PRESENTATION
}

Prasanta Kumar Nayak, Subarna Mitra, Agnes Mathew, Poornima Ramakrishnan, Somanath Padhi

1. Assistant Professor, Department of Obstetrics \& Gynaecology, Pondicherry Institute of Medical Sciences, Pondicherry.

2. Assistant Professor, Department of Obstetrics \& Gynaecology, Pondicherry Institute of Medical Sciences, Pondicherry.

3. Professor, Department of Obstetrics \& Gynaecology, Pondicherry Institute of Medical Sciences, Pondicherry.

4. Assistant Professor, Department of Obstetrics \& Gynaecology, Pondicherry Institute of Medical Sciences, Pondicherry.

5. Assistant Professor, Department of Pathology, Pondicherry Institute of Medical Sciences, Pondicherry.

\section{CORRESPONDING AUTHOR}

D. Prasanta Kumar Nayak,

E-Block(3B) PIMS Campus,

Ganapathychettikulam, Pondicherry, India

E-mail: drprasant79@gmail.com

Ph: 00918098736722

ABSTRACT: Sertoli-Leydig cell tumor (SLCT) is a rare (less than 0.5\%), primary malignant sex cord stromal tumor of ovary, which may present with or without hormonal manifestations. Literature regarding biological behavior during pregnancy and/or puerperium is sparse. We aim to report an androgen producing SLCT, in a 22 year old post partum ( 8 months) female, who presented with torsion and no clinical features of virilization. The detailed clinicopathological characteristics are presented with a review of relevant literature. SertoliLeydig cell tumor, though rare, should be kept as a differential diagnosis in the evaluation of unilateral adnexal mass with features of hyperandrogenemia. To the best of our knowledge, this is possibly the first case of SLCT presenting with torsion in the absence of virilization; inspite of biochemical evidence of androgen excess.

KEY WORDS: Sertoli-Leydig cell tumor, androgen, pregnancy, post partum, torsion.

INTRODUCTION: Sertoli-Leydig cell tumors, represent less than $0.5 \%$ of all primary ovarian tumors [1]. Approximately 1\% of ovarian malignancies discovered during pregnancy. These present over a wide age range ( 2 to 75 years, mean; 25 years) with a peak incidence $(75 \%)$ in second to third decade of life [2]. Functionally, these are androgen producing tumors and clinical virilization is noted in majority of the patients. Though low grade malignant, occasionally poorly differentiated variety may behave more aggressively. However, uncertainty remains in regard to their biologic behavior during pregnancy and/or post partum period [2-9]. Age at presentation, clinical stage, and histological grade are the most important predictors of outcome in these patients [2,3].

We aim to present the clinicopathological characteristics of a hormonally active SLCT in a young post partum female with atypical endocrinological manifestation. Besides this, literature pertaining to SLCTs in pregnancy and postpartum period is briefly discussed. 
CASE REPORT: A 22 year old female patient $\left(\mathrm{P}_{1} \mathrm{~L}_{1}\right)$ presented to Obstetrics and Gynecology outpatient department of our institute with complaints of right side flank pain and vomiting of 5 days duration. On evaluation, her vitals were stable and routine laboratory parameters were within normal range except for anemia (haemoglobin; $90 \mathrm{~g} / \mathrm{L}$, ref. 120-140 g/L), and leukocytosis (total leukocytosis; $12 \times 10^{9} / \mathrm{L}$, ref. 4-11 x 109/L). Eight months back, she delivered a term (39 weeks) male baby weighing $3.2 \mathrm{~kg}$ by normal vaginal delivery. Her peri and post partum periods were uneventful. Her routine antennal work-up did not reveal any abnormality. She experienced regular menstruation (4days/30days), at 4 months postpartum. She gave no history of prior surgery, urinary tract infection, or pelvic inflammatory disease.

Routine pelvic ultrasound, on day 2 of admission, demonstrated a right sided complex cystic ovarian mass lesion of size $11 \times 10 \mathrm{~cm}$, suggestive of a dermoid cyst without any evidence of peritoneal free fluid. Explorative laparotomy revealed an 11 x $8 \mathrm{~cm}$ cystic, well encapsulated, and multiloculated ovarian mass lesion in right side with congested surface vessels, suggestive of torsion. There was no evidence of capsular breach, surface implants, or adhesions to surrounding structures. The left side adnexal structures and the uterus were unremarkable. Cytological evaluation of peritoneal lavage fluid $(10 \mathrm{ml})$ was negative for malignancy and the level of carcinoembryonic antigen (CEA) from the aspirated cyst fluid were within normal range. Per-operative frozen section was suggestive of a malignant tumor in right ovary, following which; unilateral salpingo-oophorectomy with omental wedge biopsy was performed. The appearance of peritoneal surfaces, the surface of the liver, and the under surface of diaphragm were unremarkable. Lymph nodes were not palpable; hence lymph node dissection was not performed.

The cut section of right ovarian mass lesion showed admixture of solid and cystic areas with foci of yellowish and necrotic areas (Figure 1). Haematoxylin and eosin stained tissue sections from the mass revealed a tumor comprising of immature Sertoli cells arranged in nests forming immature tubules, cords, and trabeculae surrounded by an edematous stroma. Scattered in between Sertoli cells, were cells with moderate amount of granular eosinophilic cytoplasm and round hyperchromatic nuclei (Leydig cells). There was no evidence of any heterologous elements, retiform areas, capsular breach, or lymphovascular invasion. The tumor cells showed intense cytoplasmic positivity for alfa-Inhibin. The histomorphology was thus consistent with a Mayer's grade 2 SLCT (Figure $2 \& 3$ ).

Her serum total testosterone level, on day 4 post surgery, was very high $(1454 \mathrm{ng} / \mathrm{dL}$; ref., 15 to $81 \mathrm{ng} / \mathrm{dL}$, electrochemiluminescence immunoassay). Surprisingly, there was no evidence of any signs of virilization. Based upon the clinical stage (IA), the patient was kept on follow up without any adjuvant therapy. Follow-up serum testosterone levels at 2, 4, and 18 months post surgery were within normal reference range i.e. $41.7,13$, and $17 \mathrm{ng} / \mathrm{dL}$, respectively. The patient is free of the disease till last follow-up without any signs of hormonal abnormalities.

DISCUSSION: The present case describes, possibly for the first time, a hormonally active, ovarian SLCT in the absence of clinical signs of virilization, and presenting with torsion. A comparative review of literature regarding clinical behaviour, pathology, management, and outcome data of SLCTs (both pregnant and non pregnant cases) is presented in Table 1. A recent Chinese study [3], analysed 40 patients of ovarian SLCTs (age range; 9 to 62 yrs, mean; 28 yrs) among which thirty one (77.5\%) had signs/symptoms of hormonal excess [25/40 (63\%) virilizing, 6/40 (15\%) feminizing (post menopausal bleeding)]. Nineteen of 25 (76\%) with virilization had biochemical evidence of androgen excess. Majority (34/40, 85\%) were of 
Mayer's grade 2/3 and were managed with either surgery with or without chemoradiotherapy. Thirty six of 40 (90\%) were free of disease, one expired; and rest three were lost to follow.

The literature regarding incidence and biological behaviour of ovarian malignancies, more specifically hormone producing tumors, during pregnancy and/or puerperium is scarce. In an era when routine pelvic ultrasound becomes a part of antenatal work-up, more number of such tumors is picked up in early pregnancy [2-8]. The largest series, published till date (by Young et al) [3], described 13 cases of SLCTs (all grade I) during pregnancy and/or puerperium (6months). In 9/13, these were detected incidentally; and only 3 were functional ( 2 virilization, 1 vaginal bleed). The mean diameter was $15 \mathrm{~cm}$ (range; $3-22 \mathrm{~cm}$ ) which was comparatively larger than non pregnant cases. Seven were partly solid and cystic, 6 purely solid; and 7 had yellowish areas. Histologically, majority (10/13) were Mayer's grade 2 characterized by prominent intercellular edema (more at term), nuclear atypia, increased Leydig cells; and heterologous elements (gastrointestinal type) were observed in two. In view of marked edema and increasing size, the risk of rupture (6/13) and obstructed labour was noted more at term, necessitating early intervention; though none had any evidence of recurrence. Shitut et al [5] described a rare case of bilateral, malignant, poorly differentiated, hormonally inactive, SLCT in a young pregnant female ( $5^{\text {th }}$ month gestation) with successful pregnancy outcome (term baby; elective LSCS); and without recurrence at 18 months of follow-up. The functional inactivity of these tumors during pregnancy may be explained by the metabolic function of placenta which causes aromatization of androgens to estrogen [3]. On the contrary, recurrence of SLCTs during pregnancy with fulminant outcome was reported by others [6, 7]. Ours' is probably the first of such kind where SLCT presented with torsion, hyperandrogenemia; yet there was absence of any symptoms/signs of virilization. Presentation with torsion (possibly due to rapid increase in size) immediately post lactation, in our patient, might be due to withdrawal of the physiologic control of the hypothalamo-pituitary-gonadal axis. Furthermore, as described by researchers, differential expression and sensitivity of target tissues to androgen might be another possible explanation for paradoxical phenotype seen in our case [9].

The SLCTs may be intriguing to the Obstetricians for uncertain biology and fetal outcomes; as well as endocrinologists for their diverse phenotypic features. Virilizing SLCTs may have increased risk of infertility and subsequent poor pregnancy outcomes. Rarely, some may secrete alfa fetoprotein (AFP), present with isosexual precocious puberty, or subclinical Cushing syndrome [10-12]. These, along with adrenal tumors/hyperplasia, Cushing syndrome, intersexuality, and iatrogenic hyperandrogenemia form the spectrum of conditions that may be associated with secondary amenorrhoea and features of virilization. Measurement of plasma testosterone [ $>6.9 \mathrm{nmol} / \mathrm{L}(200 \mathrm{ng} / \mathrm{dL})]$ is a reliable and sensitive method in this context; and when supplemented with selective ovarian and/or adrenal venous catheterization/hormonal sampling (SO/AVHS) greatly facilitate in preoperative diagnosis and exact localization of SLCTs [13-15].

To conclude, SLCTs, though rare should be kept in mind while evaluating a case of unilateral adnexal mass in young; especially when there is signs/symptoms of androgen excess. The diagnosis may be quite challenging in view of atypical presentation. In view of paucity of literature, more number of such cases during pregnancy and/or post partum period should be studied for a better understanding of pathobiology of this group of tumors. 


\section{REFERENCES:}

1. Gui T, Yang J, Zhzng Y, Yu Q, Shen K, Wan X, et al. A clinicopathological analysis of 40 cases of ovarian Sertoli-Leydig cell tumors. Gynecol Oncol. 2012. doi.org/10.1016/j.ygyno.2012.07.114.

2. Giuntoli RL II, Webb MJ. Sertoli-Leydig cell tumors of the ovary and pregnancy. CME J Gynaecol Oncol. 2002; 7:134-9.

3. Young RH, Dudley AG, Scully RE. Granulosa cell, Sertoli-Leydig cell, and unclassified sex cord-stromal tumors associated with pregnancy: a clinicopathological analysis of thirtysix cases. Gynecol Oncol 1984; 18:181.

4. Behtash N, Zarchi MK, Gilani MM, Ghaemmaghami F, Mousavi A, Ghotbizadeh F. Ovarian carcinoma associated with pregnancy: a clinicopathologic analysis of 23 cases and review of literature. BMC Pregnancy and Childbirth. 2008; 8:3. doi: 10.1186/1471-23938-3.

5. Shitut PB, Deshmukh PB, Paenar V, Pandit SN. A rare case of bilateral malignant SertoliLeydig cell tumor in pregnancy. Bombay Hospital Journal 2009; 51(3):410-3.

6. Widschwendter M, Meduri G, Loosefelt H. Fulminant recurrence of Sertoli-Leydig cell tumor during pregnancy. Br J Obstet Gyaecol 1999; 106(3):284-85.

7. Ayhan A, Tuncer ZS, Hakverdi AU, Yuce K, Ayhan A. Sertoli-Leydig cell tumor of ovary: a clinicopathologic study of 10 cases. Eur J Gynecol Oncol. 1996; 17(1):75-8.

8. Horny HP, Braumann W, Weiss E, Dietl J, Kaiserling E. Virilizing stromal Leydig cell tumor of the ovary in pregnancy-A Case Report. Gen Diagn Pathol. 1995 May; 141(1): 57-60.

9. Rosenfield RL. Clinical practice: Hirsutism. N Engl J Med. 2005;353:2578-88.

10. Poli UR, Swarnalata G, Maturi R, Rao ST. Recurrent alpha-feto protein secreting SertoliLeydig cell tumor of ovary with an unusual presentation. Ind J cancer. 2009; 46:64-6.

11. Choong CS, Fuller PJ, Chu S, Jeske Y, Bowling F, Brown R, et al. Sertoli Leydig cell tumor of the ovary, a rare cause of precocious puberty in a 12 month old infant. J Clin Endocrinol Metabol. 2002; 87(1):49-56.

12. Diab DL, Faiman C, Siperstein AE, Grossman WF, Rabinowitz LO, Hamrahian AH. Virilizing ovarian Leydig cell tumor in a woman with subclinical Cushing syndrome. Endocr Pract. 2008;14(3):358-61.

13. Regnier C, Bennet A, Malet D, Guez T, Plantavid M, Rochaix P, et al. Clinical case seminar. Intraoperative testosterone assay for virilising ovarian tumor topographic assessment: Report of a Leydig cell tumor of the ovary in a premenopausal woman with an adrenal incidentaloma. J Clin Endocrinol Metab. 2002; 87(7):3074-7.

14. Chang RJ. Polycystic ovary syndrome and hyperandrogenic states. In:Yen \& Jaffe's Reproductive Endocrinology, 5th edition, Philadelphia, ELSEVIER Saunders, 2004; 597632.

15. White LC, Buchanan KD, O'Leary TD, Carlan SJ, Boothby R. Direct laparoscopic venous sampling to diagnose a small Sertoli-Leydig tumor. Gynecol Oncol. 2003;91(1):254-7. 
Table-2: Ovarian Sertoli-Leydig cell tumor: review of clinicopathological characteristics among pregnant and non pregnant females.

\begin{tabular}{|c|c|c|c|c|c|c|c|c|}
\hline $\begin{array}{l}\text { Author, } \\
\text { year, } \\
\text { referen } \\
\text { ce } \\
\end{array}$ & $\begin{array}{l}\text { No. } \\
\text { of } \\
\text { case } \\
\text { s (n) }\end{array}$ & $\begin{array}{c}\text { Age } \\
\text { range } \\
\text { (years, } \\
\text { mean) }\end{array}$ & $\begin{array}{c}\text { Clinical } \\
\text { presentation }\end{array}$ & $\begin{array}{c}\text { Biochem } \\
\text { ical } \\
\text { marker } \\
(\mathbf{n}, \%) \dagger\end{array}$ & Pathology & $\begin{array}{l}\text { FIG0 } \\
\text { stage }\end{array}$ & $\begin{array}{c}\text { Manageme } \\
\text { nt }\end{array}$ & Follow-up \\
\hline $\begin{array}{l}\text { Ting et } \\
\text { al[1], } \\
2012\end{array}$ & 40 & $\begin{array}{l}9-62 \\
(28)\end{array}$ & $\begin{array}{l}\text { Virilization; } \\
25 \text {, } \\
\text { feminization; } \\
\text { 6, abd. mass; } \\
\text { 7, rupture; } 2 \\
\end{array}$ & $\mathrm{~T}(19 / 25)$ & $\begin{array}{l}\mathrm{Gr} \neq 3-20 \\
\mathrm{Gr} 2-14 \\
\mathrm{Gr} 1-04 \\
\mathrm{UD}^{\#-02}\end{array}$ & $\begin{array}{c}\mathrm{I} \\
(40 / 40)\end{array}$ & $\mathrm{S}+\mathrm{CT} / \mathrm{RT}$ & $\begin{array}{l}\text { 36; disease } \\
\text { free, } \\
\text { 3; lost to } \\
\text { follow-up, } \\
\text { 1; expired }\end{array}$ \\
\hline $\begin{array}{c}\text { Young } \\
\text { et al [3], } \\
1984\end{array}$ & 13 & $\begin{array}{c}\text { All } \\
\text { pregnan } \\
\mathrm{t}\end{array}$ & $\begin{array}{c}\text { 9/13 } \\
\text { incidental, } 6 \\
\text { rupture, } 2 \\
\text { virilization, } 1 \\
\text { vaginal bleed }\end{array}$ & $\begin{array}{l}\mathrm{T}(2), \mathrm{E} \\
(1)\end{array}$ & $\begin{array}{l}\text { Mean size; } 15 \mathrm{~cm} \\
(3-22 \mathrm{~cm}) ; 7 \text { solid + } \\
\text { cystic, } 6 \text { purely } \\
\text { solid, } 7 \text { yellowish } \\
\text { areas, } 2 \\
\text { heterologous } \\
\text { elements (Gr } 4 \text { ) } \\
\text { (gastrointestinal } \\
\text { epithelium),10 Gr } \\
\text { 2, } 7 \text { intercellular } \\
\text { edema }\end{array}$ & $\begin{array}{c}\mathrm{I} \\
(13 / 13)\end{array}$ & USO, no CT & $\begin{array}{c}\text { No adverse } \\
\text { outcome, } \\
\text { no } \\
\text { recurrence }\end{array}$ \\
\hline $\begin{array}{c}\text { Shitut et } \\
\text { al [5], } \\
2009\end{array}$ & 1 & $\begin{array}{c}22, \\
\text { pregnan } \\
t\left(5^{\text {th }}\right. \\
\text { month })\end{array}$ & Asymptomatic & Inactive & $\begin{array}{c}\text { Bilateral } \\
\text { Left ovary: } 20 \text { x } 15 x \\
8 \mathrm{~cm} \text {, Right ovary: } \\
4 \times 2 \times 1.5 \mathrm{~cm} \\
\text { (largest), Gr } 3\end{array}$ & III & $\begin{array}{c}\mathrm{TAH}+\mathrm{BS}+ \\
\mathrm{LO}+\mathrm{LN}+\mathrm{Om} \\
+\mathrm{CT} \\
(\mathrm{Et}+\mathrm{Cs}+\mathrm{Cp})\end{array}$ & $\begin{array}{c}\text { Successful } \\
\text { pregnancy } \\
\text { outcome, } \\
\text { disease } \\
\text { free at } \\
\text { 18months } \\
\text { follow-up. }\end{array}$ \\
\hline $\begin{array}{c}\text { Ayhan } \\
\text { et al [7], } \\
1996\end{array}$ & 1 & $\begin{array}{c}\text { Pregnan } \\
\mathrm{t}\end{array}$ & - & - & - & - & - & $\begin{array}{c}\text { Recurrence } \\
\text { during } \\
\text { pregnancy, } \\
\text { expired } 16 \\
\text { weeks post } \\
\text { surgery }\end{array}$ \\
\hline $\begin{array}{c}\text { Horny } \\
\text { et al [8], } \\
1995 \\
\end{array}$ & 1 & $\begin{array}{c}21, \\
\text { pregnan } \\
t\end{array}$ & Virilizing & $\mathrm{T}$ & Benign (Gr 1) & I & USO & $\begin{array}{l}\text { Disease } \\
\text { free }\end{array}$ \\
\hline $\begin{array}{l}\text { Present } \\
\text { case, } \\
2012\end{array}$ & 1 & $\begin{array}{l}22(8 \\
\text { months } \\
\text { post } \\
\text { partum })\end{array}$ & $\begin{array}{l}\text { Torsion, no } \\
\text { signs of } \\
\text { virilization/fe } \\
\text { minization }\end{array}$ & $\mathrm{T}$ & $\begin{array}{c}\mathrm{Gr}-2, \\
\text { Intercellular edema }\end{array}$ & I & USO & $\begin{array}{l}\text { Disease } \\
\text { free at } 18 \\
\text { months } \\
\text { post } \\
\text { surgery }\end{array}$ \\
\hline
\end{tabular}

Abbreviation: $\dagger$; testosterone (T), estrogen (E), \#; Mayer's grade, \#; undifferentiated, T; surgery (S), chemotherapy (CT), radiotherapy (RT), unilateral salpingo-oophorectomy (USO), total abdominal hysterectomy (TAH), bilateral salpingectomy (BS), left oophorectomy (LO), lymphadenectomy (LN), omentectomy $(\mathrm{Om})$, etoposide (Et), cisplatin (Cs), cyclophosphamide (Cp). 


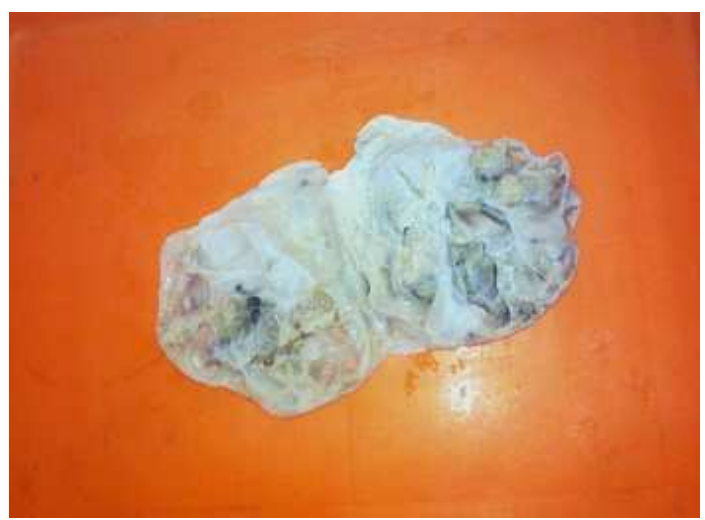

Figure 1: Cut section of the mass showing solid and cystic components with focal yellowish areas and necrosis.

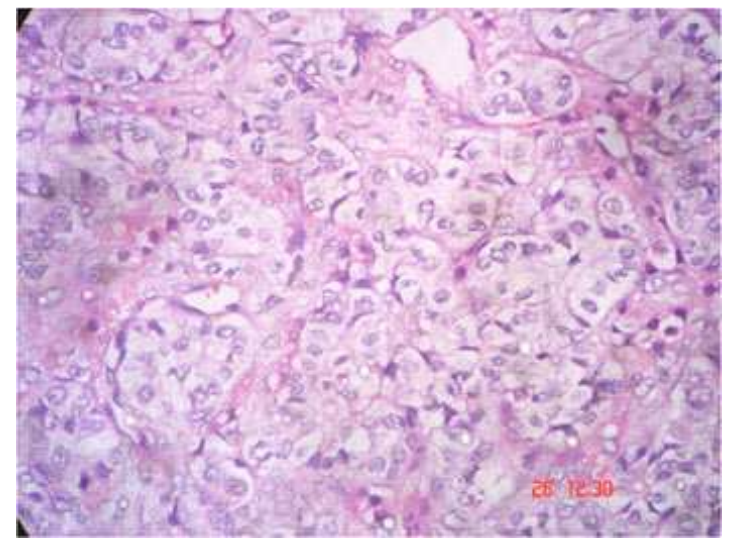

Figure 2: Stained tissue section of ovarian mass showing immature Sertoli cells forming tubule, nests, trabeculae, and intervening scattered Leydig cells with granular eosinophilic cytoplasm (Haematoxylin-eosin, 100X).

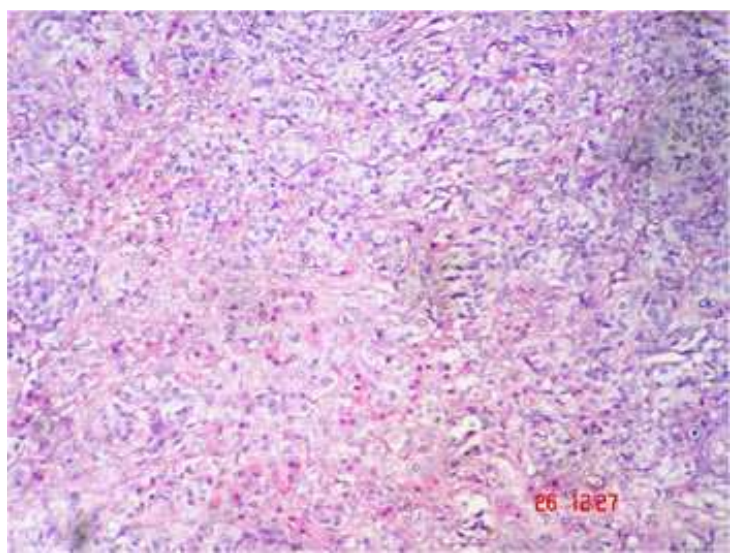

Figure 3: High power microscopic view from the mass showing Sertoli cells with vacuolated cytoplasm, round to elongated nuclei showing conspicuous nucleoli (Haematoxylin-eosin, 400X). 